\title{
ЧАСТОТА ФАКТОРОВ РИСКА СЕРДЕЧНО-СОСУДИСТОЙ СМЕРТИ У ЛИЦ С САХАРНЫМ ДИАБЕТОМ 2 ТИПА
}

Щетинина А.О., Рымар О.Д., Щербакова Л.В., Мустафина С.В., Бахарева Ю.С., Мазуренко Е.С., Малютина С.К.

Научно-исследовательский институт терапии и профилактической медицины - филиал ФГБНУ «Федеральный исследовательский Институт цитологии и генетики Сибирского отделения Российской академии наук», Новосибирск

ЦЕЛЬ: изучить частоту «традиционных» и «специфичных» факторов риска сердечно-сосудистой смерти у лиц с сахарным диабетом 2 типа (СД2).

МАТЕРИАЛЫ И МЕТОДЫ: выполнено проспективное исследование по типу гнездовой «случай-контроль» на выборке жителей, имеющих диагноз СД2, проживающих в г. Новосибирске. Период наблюдения с 2003-2005 гг. по 2017 г. Базовое обследование проведено в рамках проекта НАРІЕЕ: «Детерминанты сердечно-сосудистых заболеваний в Восточной Европе: мультицентровое когортное исследование». В группу «случай» вошли 145 человек (74 мужчины, 71 женщин, средний возраст 62,0土5,7 лет) из числа лиц с СД2, у которых за наблюдаемый период произошла сердечно-сосудистая смерть (ССС). Случаи смертности были идентифицированы путем сопоставления данных архива Отдела регистрации актов гражданского состояния о смерти по городу Новосибирску и электронной базы данных НАРІЕЕ. ССС была установлена в соответствии с кодами Международной классификации болезней 10-го пересмотра (МКБ-10): I (0-99).

Группа «контроль» - 272 человека (111 мужчин, 161 женщина, средний 57,9土6,6 года) сформирована из числа участников НAPIEE с СД2, которые продолжили наблюдение до 31 декабря 2017 г. Лица, имевшие в анамнезе на момент базового обследования нефатальные инфаркт миокарда и инсульт, были исключены. В рамках базового скрининга были собраны социально-демографические данные, параметры антропометрии (рост, вес, индекс массы тела (ИМТ), окружность талии (ОТ) и бедер (ОБ)), показатели артериального давления (АД). Из анкеты оценены физическая активность (более/менее 3 часов в неделю), семейное положение, данные о курении. Для постановки диагноза СД2 использованы критерии Американской диабетической ассоциации (2003, 2013 гг.): уровень глюкозы плазмы натощак $\geq 7,0$ ммоль/л однократно, после 8часового голодания. Также в группу с СД2 вошли лица с уровнем глюкозы натощак<7,0 ммоль/л, но указавшие, что имеют СД2 и получающие антигипергликемическую терапию.

РЕзУльтАТЫ: среди умерших за наблюдаемый период было одинаковое количество мужчин и женщин 51 и 49\%. По данным обследования на базовом скрининге обнаружено, что лица с Сд2, умершие за наблюдаемый период от СС-заболеваний, по сравнению с продолжающими наблюдение, чаще курили 25,5 против 16,9\%, p=0,037; были не женаты/разведены 17,2 против 9,9\%, p=0,032, разница достигнута за счет мужчин; имели тенденцию к увеличению лиц с ожирением (ИМТ $\geq 30$ кг/м²) - 59,3 против 49,8\%, p=0,064 разница достигнута за счет женщин, среди женщин ОТ/ОБ >0,85 была у 80,3 против 66,5\%, $p=0,033$; чаще имели АД > 140/85 мм рт.ст. - 84,8 против 75,3\%, p=0,024, разница достигнута за счет мужчин; были физически менее активны 96,9 против 76,5\%, p=0,011, разница также достигнута за счет мужчин; Сд2 был установлен до скрининга (т.е. имели большую длительность диабета) 44,1 против 31,3\%, p=0,009, разница достигнута за счет женщин.

Выводы: факторами риска смерти при СД2 являются малоподвижный образ жизни, семейное положение, курение, ожирение, артериальная гипертензия, длительность СД. Большинство из этих факторов риска относятся к категории модифицируемых, что требует внимания при планировании профилактических мероприятий и оптимизации схем лечения. 